\title{
プロスポーツチームの地域における経済的価值評価
}

\author{
石 坂 圭 三* 間 野 義 之**
}

\section{The Economic Value of Having a Professional Sports Team in a City ${ }^{\dagger}$}

\author{
Keizo ISHIZAKA* and Yoshiyuki MANO**
}

\begin{abstract}
There have been some quantitative studies about the economic impact of professional sports teams on local regions, but there hasn't been any study in Japan that quantified the value, including the intangible or public goods value of a professional sports team, for a city. The objective of this paper was to estimate the money value, including intangible value, of a professional sports team for a city by using CVM (Contingent Valuation Method) and to find if the evaluation of the public goods aspect of a professional sport team by local residents has a positive effect on WTP (willingness to pay). We selected the Japanese professional baseball team "A" and conducted CVM surveys in "B" city in which "A" team locates its home stadium. We estimated that the value of "A" team for "B" city is 141 341 million yen minimum, and $488 \sim 1,175$ million yen maximum for a year and the present value as $2.4 \sim 5.9$ billion yen minimum and 8.4 20.3 billion yen maximum. And we found that the evaluation of the public goods aspect of a professional sports team by local residents has a positive effect on WTP.
\end{abstract}

Key words : CVM, Professional Sports Team, Public Goods

\section{1.はじめに}

わが国におけるプロスポーツの収入規模は，プ 口野球では 1 球団あたり平均 100 億円 (推定 $)^{1)}$, $\mathrm{J}$ リーグでは 1 クラブあたり平均 34.5 億円（J1 のみ $)^{2)}$ と大企業と比較すれば決して大きいと はいえない。それにもかかわらず, 国民の注目 度は高く, また, 話題に事欠くことがなく, あ らゆるメディアで連日取り上げられている。こ のような状況は, プロスポーツが「スポーツと いう公共的なソフト・文化」年4) を扱っているこ
との表れであると考えられる。プロスポーツ チームの公共財（注 1) としての側面について, Johnson et al. ${ }^{5)}$ は，地域連帯感，ファンロイヤ ルティ, 市民としての誇りを示し，それらが非 競合的, 非排他的であると述べている. そして, 人々がチームのことを話題にしたり，成功のた めに応援したり，勝利を祝うことについて，そ のような行動を, 観戦チケットを購入せずとも, また，チームに対して直接支払行為をしないと しても行うかもしれないと述べている.

プロスポーツチームが地域にもたらす効果や

\footnotetext{
†原稿受付 2010 年 1 月 14 日

*早稲田大学大学院スポーツ科学研究科 = 202-0021 東京都西東京市東伏見 2-7-5

**早稲田大学スポーツ科学学術院干202-0021＼cjkstart東京都西東京市東伏見 3-4-1

${ }^{*}$ Graduate School of Sport Sciences, Waseda University, 2-7-5, Higashifushimi, Nishitokyo, Tokyo, Japan (202-0021)

** Faculty of Sport Sciences, Waseda University, 3-4-1, Higashifushimi, Nishitokyo, Tokyo, Japan (202-0021)
} 
インパクトについてはこれまでにも多くの指摘 がなされている. 原田 ${ }^{6}$ は, プロスポーツクラ ブ・球団を所有することが，地域にもたらす 4 つの社会・経済的インパクトとして, (1)社会資 本の蓄積, (2)消費の誘導, (3)地域連帯感の向上, (4)都市イメージの向上，をあげている．また，

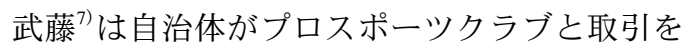
行う場合に検討されるベネフィットとして, (1) 当該地域の知名度・イメージの向上, (2)競技の 催行等に伴う経済効果, (3)クラブチームを核と する地域住民の連帯感の形成, (4)住民の健康意 識の形成, スポーツ活動への参画の促進, (5) オリティ・オブ・ライフ（QOL）の水準の向上, の 5 点を述べている. そして, 山口 ${ }^{8)}$ は, 北海 道日本ハムファイターズと東北楽天ゴールデン イーグルスの移転・新設当時の各種報道から, 球団が地元に与えた効果を, (1)経済波及効果, (2)球場周辺開発効果, (3)シティセールス効果, (4)交流施設・空間の創出, (5)球団・球場支援活 動によるコミュニティ活動の活性化, 人材交流 機会の創出等, (6)スポーツ振興, 青少年教育, と整理した。いずれにおいても, プロスポーツ チームが地域にもたらす効果について, 経済効 果といつた有形な効果のみならず, 地域住民の 連帯感向上や QOL の向上といつた Johnson et al. ${ }^{5}$ が公共財と指摘しているような無形の効果 があることが述べられている.わが国において， プロスポーツチームが地域にもたらす経済効果 については, これまでにも定量的に研究されて いる ${ }^{9)-11)}$ 。また，シンクタンク等による経済効 果の推計は数多くみられる. しかしながら, 公 共財としての無形の価值も含めて定量的にプロ スポーツチームの価值を評価した研究事例はみ られない.

一方, 欧米では, 米国での National Hockey League のチームがもたらす公共財としての価 值に関する研究5) やスペインでのプロサッカー チームがホストシティにもたらす利用価值・非 利用価值に関する研究 ${ }^{12}$ 等においてプロスポー ツチームの価值をCVM (Contingent Valuation Method：仮想市場法）と呼ばれる方法によって
評価している例がある. CVM は, 無形の価値や 非利用価值を評価することのできる数少ない方 法のひとつであり, わが国でも環境・生態系の 評価や公共事業の評価等で使用されている ${ }^{13144}$.

そこで，本稿ではわが国のプロスポーツチー ムの地域における価值について, CVM を用い て推計すること，ならびに，地域住民によるプ ロスポーツチームの公共財としての評価がプロ スポーツチームの地域における価值に影響を与 えるかについて, WTP (willingness to pay：支 払意思額）に影響を与える要因分析によって明 らかにすることを目的とした。

\section{2. 方法}

\section{1 CVM (Contingent Valuation Method):}

\section{仮想市場法について}

CVM の歴史は, 1947 年にシリアシーワント ラップが最初にアイディアを出し, 1958 年に 米国の国立公園局がデラウェア川流域のレクリ エーション価值を求めるために実際に用いたの が始まりといわれている ${ }^{19)}$. CVM の歴史で重 要なのは, その後, 1989 年のオハイオ裁判で, 司法当局が CVM を環境に対する損害補償の額 の算定の方式として認めたことである ${ }^{19)}$. わが 国では米国とは異なり司法の場で CVM が取り 上げられることはないが, 政府の公共事業評 価マニュアルの中で, 1999 年時点, 河川の環 境事業, 海岸事業, 砂防事業においてこの手法 が正式に取り上げられており，また下水道事業 でもその必要性が指摘されている ${ }^{19)}$. CVM は, もともと市場（価格）がない財・サービスの評 価を可能とする手法であり, 利用価值のみなら ず，存在することによる価值といった非利用価 值の評価もできるという特徵がある. 具体的に は，仮想的な状況を想定したアンケートをもと に, 財・サービスの変化に対する人々の金銭的 な評価 $=$ WTP (willingness to pay : 支払意思額) を直接的に聞き出し, 統計的に処理することに よって 1 人あたりの評価額を推定する. そして, その評価額を関係者全体で集計することによつ て，その財・サービスの価值を推計するという 
手順で行う。

\section{2 評価対象}

本稿での評価対象には，人気，市場規模でわ が国を代表するプロスポーツであるプロ野球 ${ }^{1516)}$ の球団を選んだ. 他のプロスポーツチーム, と りわけ Jリーグクラブの影響を避けるため, 球 団が本拠地を置く都市に, J リーグクラブ ( J 1 およびJ2）が存在しないことを条件としたと ころ， 2 市 2 球団であった。 そのうち調査協力 を得られた B 市に本拠地を置くプロ野球 $\mathrm{A}$ 球 団（以下 $\mathrm{A}$ 球団）を評価対象とした。 なお, 他のプロスポーツチームがある場合には, 調査 票の分量が多くなるという懸念があるが，同時 に両方のチームについて同様に CVM の設問を 設けて分析を実施することが考えられる.

\section{3 調査実施概要}

B 市在住の 18 歳以上（1991 年 4 月 1 日以前 生まれ）の個人を対象に標本調査を行った。住 民基本台帳より無作為に抽出した 1,500 名を対 象に，質問紙郵送法により調査を実施した。回 収期間は 2009 年 8 月 27 日〜 2009 年 9 月 28 日 とした. なお, 本調査で提示するWTP の範囲 の抽出, 質問項目の確認を目的に事前に予備調 査を実施した. 18 歳以上の男女 26 名を対象に 2009 年 6 月 1 日〜 6 月 9 日の期間で, インター ネットを利用した調査を行った。

\section{4 調査項目}

本調査では, 回答者の属性 8 項目, 生活に関 する 2 項目, B 市への愛着に関する 5 項目, A 球団に関する 21 項目, WTP に関する 5 項目の 計 41 項目について調査を実施した. そのうち 本稿の分析で用いた調査項目は, 回答者の属性 5 項目, A 球団との関わりについての 8 項目, WTP に関する 4 項目である. 調査項目は, 先 行研究 ${ }^{512)}$ を参考に, わが国および A 球団の実 情にあわせて設定した。（調査票については本 稿最後尾を参照)

\section{5 CVM の設計}

CVM では, 調査の各段階でバイアスの発生 を回避するための工夫が必要となる ${ }^{17)}$. そのた め本稿では, 栗山 ${ }^{18)}$ や肥田野 ${ }^{19)}$ の示した手順を もとに, 先行研究 ${ }^{5)}{ }^{12)}$ を参考にして CVM 調查 の設計を行った.

本稿で評価する対象は A 球団の B 市におけ る経済的価值である。本拠地を置く B 市の市 民に，A 球団が財政的に存続困難な状況にある という仮想的な状況を示し, A 球団存続を維持 するための WTP を以下のように尋ねた。

「プロ野球球団が球団を維持・発展させて いく為には，選手人件費をはじめとした多く の資金を必要としています。A 球団の財務状 態が著しく悪化し, 球団存続が困難な状況に あるとします。そこで, 球団存続を維持する ために，B市民から寄付金を集めて基金を設 立することと仮定します。あなたは，1 年あ たり○○○円の寄付金を支払つていただけま すか. お支払いただく分だけ自由に使えるお 金が減ることをよく考えて, お答えください. (回答：はい/いいえ)」

支払手段は基金への寄付金方式とし, WTP の回答形式は二段階二肢選択方式を用いた。二 段階二肢選択方式は, 初回提示額に対して支払 に同意した回答者には二回目に初回提示額より も高い提示額を提示し再度回答してもらい, 初 回提示額を拒否した回答者には初回提示額より も低い提示額に回答してもらう方式である. 初 回提示額は, 事前に実施した予備調査結果を 基に 1,000 円，3,000 円，6,000 円，10,000 円, 15,000 円の 5 段階を設定し, 調査対象者にラン ダムに金額が提示されるようにした.

\section{6 分析方法}

WTP は, ランダム効用モデルにより推定し た.プロスポーツチームが存続できない状況と なり, 状態が $\mathrm{Q}^{0}$ から $\mathrm{Q}^{1}$ へと悪化するとき, こ の状況悪化を防止する施策の価值を等価余剰測 度によって評価する. 回答者の間接効用関数 $\mathrm{U}$ が以下のように観測可能な部分 $\mathrm{V}$ と観測不可 
能な部分 $\varepsilon に$ 分かれるとする.

$$
\mathrm{U}=\mathrm{V}(\mathrm{Q}, \mathrm{M})+\varepsilon
$$

とする. ただし， M は所得である. 球団存続 のために $\mathrm{T}$ 円の負担を回答者に提示したとき, 回答者が賛成と答える確率は,

$\operatorname{Pr}[$ Yes $]=\operatorname{Pr}\left[\mathrm{U}\left(\mathrm{Q}^{0}, \mathrm{M}-\mathrm{T}\right)>\mathrm{U}\left(\mathrm{Q}^{1}, \mathrm{M}\right)\right]=$ $\operatorname{Pr}\left[\Delta \mathrm{V}>\varepsilon^{1}-\varepsilon^{0}\right]=1-\mathrm{G}(\mathrm{T}) \cdots(1)$

また

$\operatorname{Pr}[\mathrm{No}]=\mathrm{G}(\mathrm{T})$

となる。ただし， $\Delta \mathrm{V}$ は観測可能な効用関数 の差である.ここで $\mathrm{G}$ をロジスティック分布 と仮定する。 そして, 式 (1) は次のように与 えられる。

$$
\operatorname{Pr}[\text { Yes }]=1-\frac{\exp ^{-\Delta v}}{1+\exp ^{-\Delta v}}=\frac{1}{1+\exp ^{-\Delta v}}
$$

二段階二肢選択方式の場合は, 最初に提示額 $\mathrm{T}$ を示し，賛成と答えた人には高い金額 $\mathrm{T}^{\mathrm{U}}$ を示 し，反対と答えた人には低い金額 $\mathrm{T}^{\mathrm{L}}$ 示す. それぞれの回答が得られる確率は, 以下の通り となる.

$$
\begin{aligned}
& \operatorname{Pr}[\mathrm{Yes} / \mathrm{Yes}]=\operatorname{Pyy}=1-\mathrm{G}\left(\mathrm{T}^{\mathrm{U}}\right) \\
& \operatorname{Pr}[\mathrm{Yes} / \mathrm{No}]=\operatorname{Pyn}=\mathrm{G}\left(\mathrm{T}^{\mathrm{U}}\right)-\mathrm{G}(\mathrm{T}) \\
& \operatorname{Pr}[\mathrm{No} / \mathrm{Yes}]=\operatorname{Pny}=\mathrm{G}(\mathrm{T})-\mathrm{G}\left(\mathrm{T}^{\mathrm{L}}\right) \\
& \operatorname{Pr}[\mathrm{No} / \mathrm{No}]=\operatorname{Pnn}=\mathrm{G}\left(\mathrm{T}^{\mathrm{L}}\right)
\end{aligned}
$$

次に $\Delta \mathrm{V}$ の特定化を行う。この関数型には, 一般に次のような線形関数や対数線形関数が用 いられることが多い.

$$
\text { 線形関数モデル } \quad \Delta \mathrm{V}=\mathrm{a}-\mathrm{bT} \cdots \cdots \text { (2) }
$$$$
\text { 対数線形関数モデル } \Delta \mathrm{V}=\mathrm{a}-\mathrm{blog} \mathrm{T} \cdots \text { (3) }
$$

後は最尤法によりパラメータ $\mathrm{a}$ 及び $\mathrm{b}$ を推定す ることで, 支払意思額が得られる. 尤度関数は 以下の通りである.

$$
\begin{aligned}
\ln L= & \sum_{\mathrm{i}}\left\{\mathrm{d}_{\mathrm{i}}^{\mathrm{yy}} \ln \text { Pyy }+\mathrm{d}_{\mathrm{i}}^{\mathrm{yn}} \ln \text { Pyn }+\mathrm{d}_{\mathrm{i}}^{\mathrm{ny}} \ln \text { Pny }+\right. \\
& \left.\mathrm{d}_{\mathrm{i}}^{\mathrm{nn}} \ln \text { Pnn }\right\}
\end{aligned}
$$

ただし, $\mathrm{d}^{\mathrm{yy}}$ は回答者が 2 回とも賛成と答えた ときに 1 , それ以外のときは 0 となるダミー変 数であり, $\mathrm{d}^{\mathrm{yn}}, \mathrm{d}^{\mathrm{ny}}, \mathrm{d}^{\mathrm{nn}}$ もそれぞれ同様のダミー 変数である. 本稿では, 回答者の効用関数の差 として対数線形関数 (3) を想定した.

支払意思額は中央值 $(\operatorname{Pr}[\mathrm{Yes}]=0.5$ すなわ ち賛成と答える確率が $50 \%$ となるときの支払
意思額の值）あるいは平均値（Pr [ Y Yes] の確率 分布曲線の下側の面積が支払意思額の值）に よって決定される。平均值の場合，一般に最大 提示額までの面積に基づいて計算する ${ }^{18)}$. WTP の平均值と中央值のどちらを用いるかは, 論争 が交わされており, 多数決ルールに基づく中央 值を用いるべきとの主張がある一方で, 費用便 益分析に用いるためには平均值が望ましいとの 主張もある ${ }^{13)}$.

WTP の推計とその要因分析には, 栗山 ${ }^{20)}$ の解析ソフトを用い, その他の分析には IBM SPSS Statistics 18 を使用した.

\section{3. 結果}

\section{1 回収結果}

配布数 1,500 通から配達不能 2 通を除 $<1,498$ 通の実配布数に対し 439 通を回収し，回収率は $29.3 \%$ であった，完全無回答およびWTPにつ いての設問へ無回答であった調査票を除外した 有効回答数は 434 となり, 有効回答率は $29.0 \%$ であった。

\section{2 回答者の属性}

回答者の属性を表 1 に示した。性別は男性 が $47.7 \%$ ，女性が $52.3 \%$ ，平均年齢は 54.1 歳で あった. 2009 年 9 月末日現在の B 市住民基本 台帳における 18 歳以上の性別の割合は男性が $49.8 \%$, 女性が $50.2 \%$, 平均年齢は 49.0 歳であつ た。なお，年収については，回答者個人の年収 を尋ねた。

\section{3 二段階二肢選択方式 WTP の回答結果}

各提示額に対する回答状況は表 2 のとおりと なった。 通常の CVM の研究と同様に提示額が 高くなるにつれて「はい」と回答する確率が低 下する結果となつた. 表中にある抵抗回答とは, 回答者が支払手段に反対であったり，詳細が不 明である等の理由で，示されたシナリオに納得 できないために自己の支払意志額をゼロとした 回答である ${ }^{19)}$. 本稿では, 支払拒否理由として, 「球団は必要と認識しているが，寄付金による 
表 1 回答者の属性

\begin{tabular}{|c|c|c|c|}
\hline & & 度数 & $\%$ \\
\hline \multirow{11}{*}{ 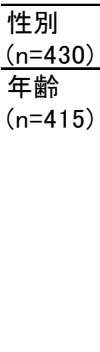 } & 男性 & 205 & 47.7 \\
\hline & 女性 & 225 & 52.3 \\
\hline & 18〜19歳 & 3 & 0.7 \\
\hline & 20～29歳 & 37 & 8.9 \\
\hline & $30 \sim 39$ 歳 & 60 & 14.5 \\
\hline & 40～49歳 & 56 & 13.5 \\
\hline & 50～59歳 & 74 & 17.8 \\
\hline & $\begin{array}{l}60 \sim 69 \text { 歳 } \\
\end{array}$ & 100 & 24.1 \\
\hline & 70〜 79歳 & 71 & 17.1 \\
\hline & $80 \sim 89$ 歳 & 14 & 3.4 \\
\hline & 平均 & 54.1 歳 & \\
\hline \multirow{8}{*}{$\begin{array}{l}\text { 職業 } \\
(n=433)\end{array}$} & 勤め人(常勤) & 141 & 32.6 \\
\hline & パート(非常勤) & 52 & 12.0 \\
\hline & 自営業 & 34 & 7.9 \\
\hline & 農業 & 6 & 1.4 \\
\hline & 学生 & 6 & 1.4 \\
\hline & 家事専従 & 88 & 20.3 \\
\hline & 無職 & 98 & 22.6 \\
\hline & その他 & 8 & 1.8 \\
\hline
\end{tabular}

\begin{tabular}{|c|c|c|c|}
\hline & & 度数 & $\%$ \\
\hline 年収 & $0 \sim 199$ 万円 & 164 & 39.0 \\
\hline \multirow[t]{6}{*}{$(n=421)$} & 200万円～399万円 & 127 & 30.2 \\
\hline & 400万円～599万円 & 68 & 16.2 \\
\hline & 600万円〜 799万円 & 28 & 6.7 \\
\hline & 800万円～999万円 & 21 & 5.0 \\
\hline & 1000万円〜 1499万円 & 10 & 2.4 \\
\hline & 1500万円以上 & 3 & 0.7 \\
\hline \multirow{6}{*}{$\begin{array}{l}\text { 世帯人数 } \\
(n=426)\end{array}$} & 1人 & 26 & 6.1 \\
\hline & 2 人 & 144 & 33.8 \\
\hline & 3 人 & 110 & 25.8 \\
\hline & 4人 & 95 & 22.3 \\
\hline & 5人以上 & 51 & 12.0 \\
\hline & 平均 & 3.1 人 & \\
\hline
\end{tabular}

表 2 各提示額に対する回答状況

\begin{tabular}{|c|c|c|c|c|c|c|c|}
\hline $\begin{array}{c}\text { 初回提示額 } \\
\text { (2nd up/down) }\end{array}$ & & $Y Y^{\prime}$ & YN & NY & NN & 合計 & $\mathrm{PN}^{2}$ \\
\hline \multirow{2}{*}{$1000(3000 / 500)$} & 度数 & 16 & 28 & 15 & 29 & 88 & 8 \\
\hline & $\%$ & $18.2 \%$ & $31.8 \%$ & $17.0 \%$ & $33.0 \%$ & $100.0 \%$ & \\
\hline \multirow{2}{*}{$3000(6000 / 1000)$} & 度数 & 6 & 24 & 20 & 30 & 80 & 8 \\
\hline & $\%$ & $7.5 \%$ & $30.0 \%$ & $25.0 \%$ & $37.5 \%$ & $100.0 \%$ & \\
\hline \multirow{2}{*}{$6000(10000 / 3000)$} & 度数 & 12 & 7 & 21 & 36 & 76 & 10 \\
\hline & $\%$ & $15.8 \%$ & $9.2 \%$ & $27.6 \%$ & $47.4 \%$ & $100.0 \%$ & \\
\hline \multirow{2}{*}{$10000(15000 / 6000)$} & 度数 & 6 & 10 & 6 & 53 & 75 & 14 \\
\hline & $\%$ & $8.0 \%$ & $13.3 \%$ & $8.0 \%$ & $70.7 \%$ & $100.0 \%$ & \\
\hline \multirow{2}{*}{$15000(20000 / 10000)$} & 度数 & 6 & 3 & 3 & 52 & 64 & 11 \\
\hline & $\%$ & $9.4 \%$ & $4.7 \%$ & $4.7 \%$ & $81.3 \%$ & $100.0 \%$ & \\
\hline
\end{tabular}

注. 1 YYは初回提示額と2nd up両方にYESと回答したことを示す. YNは初回提示額に

YES, 2nd upにNOと回答したことを示す. NYは初回提示額にNO, 2nd downにYES

と回答したことを示す. NNは初回提示額と2nd down両方にNOと回答したことを示

す.

2 PNはprotest no(抵抗回答)の略.

支援に反対である」と回答したものを抵抗回答 とした。なお，抵抗回答データと抵抗回答を除 いたデータとの間で性別・年代について $\chi^{2}$ 検 定を行ったところ, 有意差がなかったことから, 以降の分析で, 抵抗回答は除外することにした.

\section{4 WTP の推定と TWTP の推計}

通常 CVM を用いて, 財・サービスやプロジェ クトの価值を推定する際に, その算出は次のよ うな式を利用する。本稿においても B 市にお ける $\mathrm{A}$ 球団の評価額をこの式に基づいて算出
表 3 WTP 推定結果

\begin{tabular}{|c|c|c|c|}
\hline 変数 & 係数 & $\mathrm{t}$ 值 & \\
\hline （定数） & 7.993 & 13.745 & $* * *$ \\
\hline 提示額(対数值) & -1.075 & -14.544 & $* * *$ \\
\hline $\mathrm{n}$ & 383 & & \\
\hline 対数尤度 & -453.313 & & \\
\hline \multirow{2}{*}{\multicolumn{3}{|c|}{$\begin{array}{l}\text { WTP (平均値) 最大提示額で裾切り } \\
\text { WTP (中央値) }\end{array}$}} & 4086 \\
\hline & & & 1695 \\
\hline
\end{tabular}

した.

評価対象の価值 $=1$ 人あたり $\mathrm{WTP} \times$ 集計母 集団（世帯数や個人数）×評価期間 
表 4 B 市におけるA 球団の価值の推計

\begin{tabular}{|c|c|c|c|c|c|c|}
\hline & \multirow{2}{*}{ B市民数 (人) ${ }^{1}$} & \multicolumn{3}{|c|}{ WTP $(\text { 円 })^{2} \frac{\text { TWTP }(\text { 百万円 })^{3}}{2}$} & \multicolumn{2}{|c|}{$\underline{\mathrm{NPV}(\text { 億円 })^{4}}$} \\
\hline & & & 上限 ${ }^{5}$ & 下限 ${ }^{6}$ & 上限 ${ }^{5}$ & 下限 ${ }^{6}$ \\
\hline 平均値 & \multirow{2}{*}{287,711} & 4,086 & 1,175 & 341 & 203 & 59 \\
\hline 中央値 & & 1,695 & 488 & 141 & 84 & 24 \\
\hline \multicolumn{7}{|c|}{ 注. 1 2009年9月末日現在のB市住民基本台帳における18歳以上の市民数 } \\
\hline $2 \mathrm{E}$ & \multicolumn{6}{|c|}{ B市民一人の 1 年あたりWTP } \\
\hline $3 \mathrm{E}-2 \mathrm{r}-\mathrm{r} \cdot \mathrm{r}$ & \multicolumn{6}{|c|}{ B市民全体の1年あたりTWTP } \\
\hline 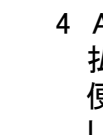 & \multicolumn{6}{|c|}{$\begin{array}{l}\text { A球団が今後 } 30 \text { 年B市に存続すると想定し, TWTPが } 30 \text { 年間, 同額で支 } \\
\text { 払われると仮定した場合の現在価値. 割引率は「公共事業評価の費用 } \\
\text { 便益分析に関する技術指針」(国土交通省,2009)の社会的割引率=4\%と }\end{array}$} \\
\hline 5 & \multicolumn{6}{|c|}{$\begin{array}{l}\text { した. } \\
\text { 上限は, 調査に回答しなかった } 71 \% \text { の調査対象者のWTPも本調査と同じ }\end{array}$} \\
\hline 6 & \multicolumn{6}{|c|}{$\begin{array}{l}\text { 下限は, 調査に回答しなかった } \\
\text { た場合＝上限金額に有効回答率29\%を調査対象者のWTPがゼロと想定した金額. }\end{array}$} \\
\hline
\end{tabular}

WTP を推定した結果, 1 年あたり WTP は平 均值で 4,086 円, 中央值で 1,695 円と推定され た（表 3 ). 続いて, 推定されたWTP を用い て, 総評価額 (TWTP : total willingness to pay) を算出した (表 4).WTP の代表値には, 中央 值と平均值があるが, どちらの指標も一長一短 があり，どちらを採用するかは意見が割れてい るため ${ }^{17)}$ ，ここでは併記することにした。 B 市 における A 球団の TWTPは, 平均值を用いて 試算した場合は, 上限で 1 年あたり 11.75 億円, 下限で 3.41 億円となり, 中央値を用いた場合 は上限で 4.88 億円, 下限で 1.41 億円と推計さ れた。 なお, 上限とは, 調査に回答しなかっ た $71 \%$ の調査対象者の WTP も本調査の結果と 同様であると想定した場合であり, 一方, 下限 とは, 調査に回答しなかった $71 \%$ の調査対象 者のWTPがゼロであると想定した場合（上限 金額に有効回答率 29\% を掛けた金額）である. A 球団はB 市に移転してから 30 年が経過して いる. 仮に A 球団が今後 30 年間 B 市に本拠地 を置き, TWTPが 30 年間支払われると想定し た場合, その現在価值は, 平均值では下限で 59 億円, 上限で 203 億円, 中央值では下限で 24 億円, 上限で 84 億円と推計された（割引率 には国土交通省が「公共事業評価の費用便益分 析に関する技術指針」で示している社会的割引 率 $=4 \%$ を設定した ${ }^{21)}$ ).

\section{5 WTP の要因分析}

次に, WTP に影響を与える要因についての 分析結果を示す.

\subsection{1 分析に用いる変数}

分析に用いた変数は表 5 のとおりである. 先 行研究5) ${ }^{12}$ を参考にして, 回答者の属性項目で ある年齢, 性別, 年収, 世帯人数と利用価值を 表すスタジアム観戦日数（年）や非利用価值を 表す PublicGoods, 優勝パレード等の変数を設 定した. PublicGoodsは, プロスポーツチーム がもたらす公共財としての側面の消費度合いを 示す変数であり, 以下の 4 つの変数の合計值で ある. (1)新聞雑誌（A 球団の記事を新聞雑誌で 週 2 日以上読むかどうか), (2)話題（家族や仲 間と A 球団のことを週 2 日以上話題にするか どうか), (3)動向 (A 球団の動向が気になるか どうか), (4)日常 (A 球団があることで日常生 活が充実するかどうか). なお，4 変数におけ る Cronbach の $\alpha$ 係数は, 0.7 以上（0.734）で あり, 信頼性は高いと判断した. Johnson et al. ${ }^{5)}$ は, 優勝という特別なイベントを祝うことも公 共財としての側面の消費の一面であるとし, 優 勝時の祝いを変数として加えている. 本稿でも これに倣い，A 球団が優勝した際にB市内で 実施された優勝パレードを沿道またはテレビで 見たかどうかを表す変数も PublicGoods とは別 に, 公共財の消費度合いを示す変数として設定 
表 5 要因分析に用いた変数の一覧

\begin{tabular}{|c|c|c|c|c|c|c|}
\hline 変数 & 内容 & $\mathrm{n}$ & 最小値 & 最大値 & 平均値 & 標準偏差 \\
\hline 年齢 & 数値データ & 366 & 18 & 89 & 53.36 & 16.53 \\
\hline 性別 & 男性 $=1$,女性 $=0$ & 380 & 0 & 1 & 0.48 & 0.50 \\
\hline 年収 (個人) & 範囲の中央值 (百万円), 数值データ & 371 & 100 & 1500 & 344.74 & 284.54 \\
\hline 世帯人数 & 数值データ & 377 & 1 & 12 & 3.07 & 1.32 \\
\hline スタジアム観戦日数(年) & 数値データ & 373 & 0 & 30 & 1.35 & 3.55 \\
\hline テレビ観戦日数(年) & 数値データ & 368 & 0 & 144 & 15.65 & 29.28 \\
\hline スタジアム観戦意図 & 観戦したい=1,他=0 & 372 & 0 & 1 & 0.50 & 0.50 \\
\hline Public Goods & 以下4項目(新聞雑誌,話題,動向,日常生活)の合計値 & 361 & 0 & 4 & 1.35 & 1.38 \\
\hline 新聞雑誌 & A球団の記事を週に2日以上読む=1,他=0 & 371 & 0 & 1 & 0.40 & 0.49 \\
\hline 話題 & A球団について週に2日以上話題にする $=1$,他 $=0$ & 371 & 0 & 1 & 0.26 & 0.44 \\
\hline 動向 & A球団の動向が気になる=1,他=0 & 366 & 0 & 1 & 0.46 & 0.50 \\
\hline 日常生活 & A球団があることで日常生活が充実する=1,他=0 & 370 & 0 & 1 & 0.22 & 0.42 \\
\hline 優勝パレード & 沿道またはテレビで見た=1,他=0 & 371 & 0 & 1 & 0.48 & 0.50 \\
\hline
\end{tabular}

表 6 対数線形ロジットモデルによるWTP の要因分析結果

\begin{tabular}{lrrll}
\hline \multicolumn{1}{c}{ 変数 } & \multicolumn{1}{c}{ 係数 } & \multicolumn{1}{c}{$\mathrm{t}$ 值 } & \multicolumn{1}{c}{$\mathrm{p}$ 值 } & \\
\hline (定数) & 7.071 & 8.124 & 0.000 & $* * *$ \\
提示額(対数值) & -1.383 & -13.396 & 0.000 & $* * *$ \\
年収(個人) & 0.002 & 3.491 & 0.001 & $* *$ \\
年齢 & 0.018 & 2.180 & 0.030 & $*$ \\
性別 & -0.323 & -1.033 & 0.302 & \\
世帯人数 & 0.110 & 1.326 & 0.186 & \\
スタジアム観戦日数(年) & 0.094 & 1.972 & $0.049 *$ \\
テレビ観戦日数(年) & 0.005 & 0.832 & 0.406 & \\
スタジアム観戦意図 & 0.615 & 2.137 & $0.033 *$ \\
PublicGoods & 0.312 & 2.416 & $0.016 *$ \\
優勝パレ一ド & 0.800 & 2.916 & $0.004 * *$ \\
\hline $\mathrm{n}$ & 328 & & & \\
対数尤度 & -340.960 & & & \\
\hline & $* * *: p<.001, * *: p<.01, *: p<.05$
\end{tabular}

従属変数:WTP設問にYESと答える確率

\section{した.}

\subsection{WTP 要因分析の結果}

WTP の要因は, 対数線形ロジットモデルに より分析した (表 6 )。 その結果, 年収 (個人)・ 優勝パレードが $1 \%$ 水準, PublicGoods・年齢・ スタジアム観戦意図・スタジアム観戦日数（年） が 5\% 水準で有意に影響があり符号はすべて正 を示した. 性別・世帯人数・テレビ観戦日数 (年) は，有意な結果とはならなかった。

\section{4. 考察}

先述したとおり, A 球団を評価対象とした, B 市民 1 人の 1 年あたり WTP は平均值で 4,086 円, 中央值で 1,695 円と推定された. 推定され た WTP を先行研究と比較してみたい. Johnson et al. ${ }^{5)}$ は, 米国の National Hockey League のチー
ムを評価対象として，WTPを462 円〜763 円 （US\$4.2〜US\$6.94を 110 円/US\$で換算） と 推定し, Castellanos ${ }^{12)}$ は, スペインのプロサッ カーチームを評価対象として, WTPを4,508 円（€ 33.39 を 135 円/€で換算）と推定した. A 球団の評価額は, スポーツが文化として根付 いているといわれる欧米での事例と比較しても 遜色のない結果であり, わが国でのプロスポー ツチームの社会的地位は低くはないことが示唆 された. また, A 球団の B 市における 1 年あ たりの価值や今後 30 年間の現在価值は, 決し て小さい金額とはいえず，今後 $\mathrm{A}$ 球団と B 市 や B 市民が双方向にさらに関係構築を図って いくことが期待される.

WTP の要因分析においては, プロスポーツ チームの公共財としての側面の消費度合いを表 
す変数である PublicGoods と優勝パレードの双 方が正に有意な影響があるという結果となっ た.これは $\mathrm{A}$ 球団に公共財としての価值があ るとみている人ほど, 支払意志が高いというこ とを示している. すなわち, 欧米のプロスポー ツチームの先行研究 ${ }^{512)}$ の結果と同様に, わが 国のプロスポーツチームにも公共財としての価 值があることが明らかになった. また，プロス ポーツチームの利用価值を表すスタジアム観戦 日数 (年) も正に有意な影響がある結果となり, 直接的に A 球団の財を消費する人ほど支払意 志が高いということも判明した。

プロスポーツチームにとつて, 地域や自治体 は重要なステークホルダーであるといわれてお り ${ }^{3) 7)}$, 本稿で得られた結果は, プロスポーツ チームの公共財としての価值をあらわす実証 データとして, その重要性の一端を示すことが できたと考えられる.

本稿では A 球団の B 市における価值を推計 したが, これまでにわが国で CVM によりプロ スポーツチームの価值を推計した研究はみられ ない. 本稿での結果を比較検証し, さらに研究 を発展させていくために, 他球団や他競技の研 究が望まれる.

\section{5.まと め}

本稿では A 球団のB市における価值を, CVM を用いて推計し, 1 年あたりの価值を下 限では 1.41 億円〜3.41 億円，上限では 4.88 億 円〜 11.75 億円, 今後 30 年間の現在価值を下 限では 24 億円〜 59 億円, 上限では 84 億円〜 203 億円と算出した. また, WTP の要因分析 によって, 地域住民によるプロスポーツチーム の公共財としての評価がプロスポーツチームの 地域における価值に正に影響を与えることを明 らかにした。

（注 1 ） 公共財とは, 多数の人々が恩恵を受ける財 のことであるが, 厳密には公共財とは「非排除性」 と「非競合性」の性質を持つ財として定義され $ろ^{18)}$.

\section{参 考 文 献}

1 ）小林至 ; 合併, 売却, 新規参入, たかが・..さ れどプロ野球!, 宝島社, p.231, 2004.

2) Jリーグ ; J リーグ 2008 年度（平成 20 年度） J クラブ個別経営情報開示資料, http : //www. j-league.or.jp/aboutj/jclub/2008-9/pdf/club2009. pdf.

3 ）広瀬一郎；スポーツリーグ産業の構造・特 質・リスク, 一橋ビジネスレビュー, Vol.56, No.4, pp.4-18, 2009.

4 ) 内海和雄 ; プロ・スポーツ論ースポーツ文化 の開拓者一, 創文企画, 2004.

5 ) Johnson, B. K., et al. ; The value of public goods generated by a major league sports team, Journal of Sports Economics, 2, pp.6-21, 2001.

6 ) 原田宗彦 ; スポーツビジネスの発展, 山下秋 二, 原田宗彦編著 : 眓解スポーツマネジメン 卜, 大修館書店, pp.56-67, 2005.

7 ) 武藤泰明 ; プロスポーツクラブのマネジメン 卜, 東洋経済新報社, 2006.

8 ）山口まみ; 球団本拠地一地域密着型経営へ 変貌しつつあるプロ野球一, Best Value, 12, 2006.

9 ）宮本勝浩, 他; プロ野球産業の経済効果, スポー ツ産業学研究, Vol.17, No.1, pp.45-56, 2007.

10）南 博；プロサッカーチームが北九州市に与 える経済効果に関する研究, 北九州市立大学 都市政策研究所 2008 年度地域課題研究, pp.187-210, 2009.

11）加藤清孝, 葉聰明; プロバスケットボールク ラブ設立が地方都市にもたらす経済効果の推 計, スポーツ産業学研究, Vol.19, No.1, pp.6773, 2009.

12) Castellanos, P. and Sanchez, M. ; The economic value of a sport club for a city : Empirical evidence from the case of a Spanish football team, Urban Public Economics Review, 7, pp.13-39, 2007.

13）栗山浩一; 環境の価值と評価手法－CVMによ る経済評価, 北海道大学図書刊行会, 1998.

14）佐藤博樹他；家庭系一般廃棄物処理サービス の経済評価 -2 段階 DCCVM の北海道北見市 への適用一, 地域学研究, Vol.28, No.1, pp.114, 1997.

15）社団法人中央調査社 ; 第 17 回人気スポーツ調 
查, p.3, 2009, http : //www.crs.or.jp/pdf/sports09. pdf.

16）ぴあライブ・エンターテインメント白書 2009 , ぴあ総合研究所株式会社, pp.116-117, 2009.

17）高木朗義；CVM（仮想市場評価法），伊多波良 雄編著; 公共政策のための政策評価手法, 中 央経済社, pp.181-202, 2009.

18）栗山浩一; 公共事業と環境の価值 CVM ガイ
ドブック，築地書館， 1997.

19）肥田野登；環境と行政の経済評価 CVM（仮 想市場法）マニュアル，勁草書房，1999.

20）栗山浩一; Excel でできる CVM 第 3.1 版, http : //homepage1.nifty.com/kkuri/.

21）国土交通省；公共事業評価の費用便益分析に 関する技術指針（共通編）, pp.5-6, 2009. 


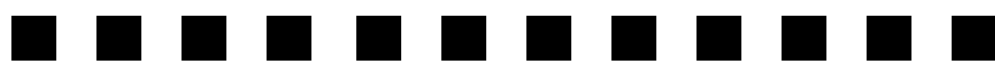

B 市のプロスポーツチーム (A 球団)に関するアンケート =調査票 samp le= アンケートにご協力頂き有難うございます。以下の項目について、あなたの考えをお聞かせ下さい。

選択式の回答は、該当筒所のマークを塗り潰してご回答ください。

$$
\text { : : 空白マークの例 } \quad \mathbf{I} \text { : 正しい塗り潰しの例 } \quad \forall \text { : 不十分な塗り潰しの例 }
$$

この用紙は機械で処理します。用紙を污したり、折り目を付けたりしないようにご注意ください。

【最初に、あなた自身のことについてお尋ねします。これらの項目は統計的な分析をおこなうために必 要なものですので、ご協力をお願い致します。】

(1)あなたの性別をお答えください。
1: 男
2: 女

(2)あなたの年齢をお答えください。（記入例：30歳 $\rightarrow 30 ）$

(3)あなたの主な職業をお答えください。(マークはひとつ)
1 : 勤め人 (常勤)
2: パート(非常勤)
3: 自営業
4: 農業
5: 学生
6: 家事専従
7: 無職
8: その他(具体的に:

(4)あなたのお住まいの郵便番号 ( 7 ケタ)をご記入ください。（記入例 : XXX-XXXX)

$$
\mathrm{XXX-}
$$

(5)あなたはB市に通算でどのくらいの期間住んでいますか。

( ) 年 ( ) ケ月

(6)あなたの世帯の人数をご記入ください。あなた自身を含めてお答えください。（記入例 : 3 人 $\rightarrow 3 ）$

(7)あなたの生活に関して、以下の項目をどう思いますか。「1：非常に不満」から「7 : 非常に満 足」でお答えください。(それぞれマークはひとつ)

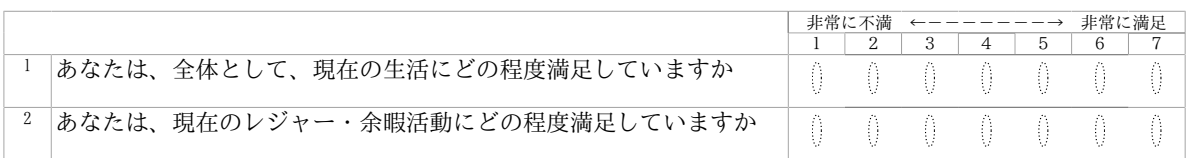

(8) B市について、以下の項目をどう思いますか。「1：全くそう思わない」から「7：非常にそう思 う」でお答えください。(それぞれマークはひとつ)

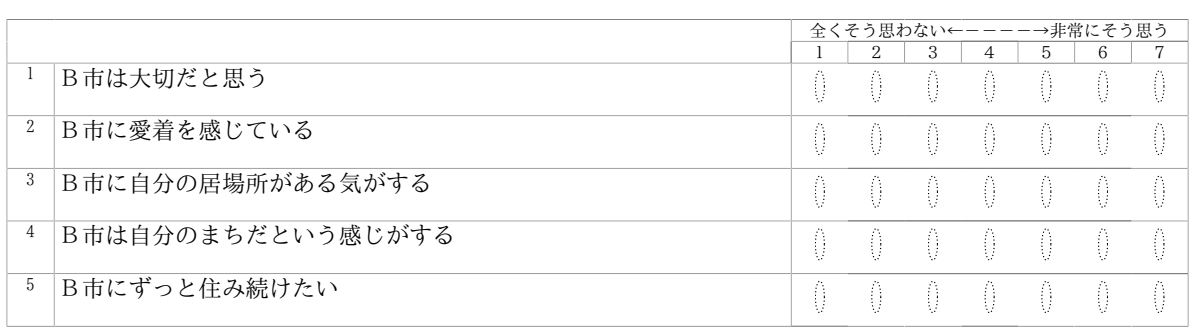

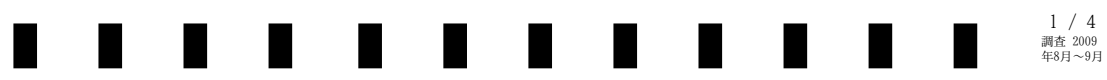




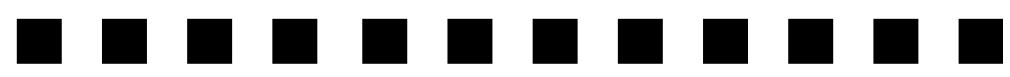

（9）あなたは過去に野球を（運動部・クラブ・サークルに所属して）行った経験はありますか。当ては まるものを以下の中からお選びください。(マークはいくつでも)
$1:$ 小学生の時
2: 中学生の時
3: 高校生の時
4: 大学生の時
5: 社会人の時
6: マネージャー(時期問わず)
7 : 野球経験はない

【次に、A球団について、あなたのお考えをお尋ねします。】

(10)あなたはA球団を応援していますか。(マークはひとつ)
$1:$ は
2: いいえ
3:どちらでもない

(11)【設問(10)で「はい」とお答えされた方にお尋ねします。】あなたが応援しているA球団に関し て、以下の項目をどう思いますか。「1：全くそう思わない」から「7 : 非常にそう思う」でお答えく ださい。(それぞれマークはひとつ)

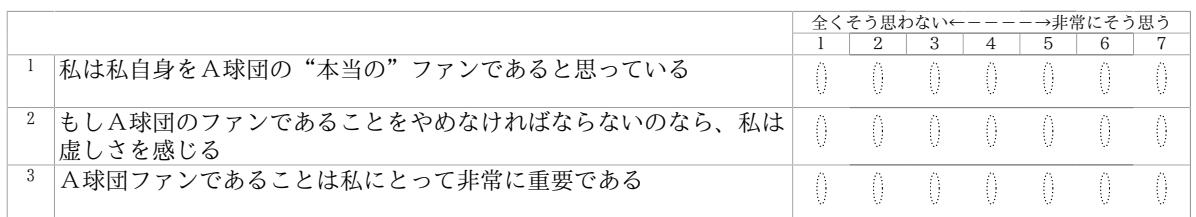

(12)あなたは 1 年あたりどのくらいA球団の試合をスタジアムで観戦しますか。（観戦している場合に は 1 にマークをつけ、1 年あたりの日数をご記入ください。観戦していない場合には 2 にマークをつけ てください。)
1: 1 年あたり (
) 日くらい
2: 観戦しない

(13)【設問(12)で「観戦しない」とお答えされた方にお尋ねします。】スタジアムで観戦しないのは何 故ですか。(マークはいくつでも)

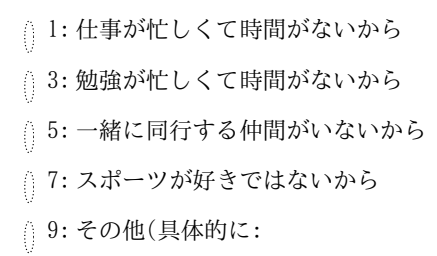
2: 家事・育児が忙しくて時間がないから
4: きっかけがないから
6: お金がかかるから
8: スタジアムまでの交通が不便だから

$$
\text { ) }
$$

(14)【設問(12)で「観戦しない」とお答えされた方にお尋ねします。】何があれば、スタジアムで観戦 しますか。(マークはいくつでも)
1: 家族・友人・仲間などに誘われたら
2: チケットをもらったら
3: 周囲で盛んに話題になったら
4: 興味のあるイベントが開催されたら
5: その他(具体的に:

(15)あなたはシーズン中にA球団の試合をどのくらいテレビで観戦しますか。（観戦している場合には 1にマークをつけ、「年・月・週」のうちひとつに○をし、日数をご記入ください。観戦していない場 合には 2 にマークをつけてください。)
$1:$ 年・月・週］あたり
) 日くらい
2: 観戦しない

(16)あなたはシーズン中にA球団のニュースを新聞や雑誌等でどのくらい読みますか。（読んでいる場 合には、1にマークをつけ、「年・月・週」のうちひとつに○をし、日数をご記入ください。読んでい ない場合には 2 にマークをつけてください。)
1: [ 年・月・週 ] あたり (
） 日くらい
2: 読んでない 


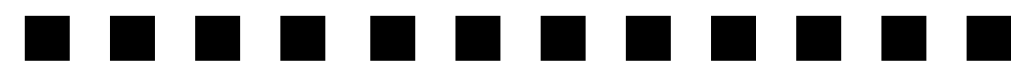

(17) あなたはシーズン中にA球団のことを家族や友人、同僚等との間でどのくらい話題にしますか。 （話題にする場合には、1にマークをつけ、「年・月・週」のうちひとつに○をし、日数をご記入くだ さい。話題にしない場合には 2 にマークをつけてください。)
$1:$ 年・月・週］あたり (
) 日くらい
2: 話題にしない

(18) あなたは 1 年あたりどのくらいA球団の社会貢献活動 $(*)$ に触れる機会がありますか。（機会がある 場合には 1 にマークをつけ、1 年あたりの日数をご記入ください。機会がない場合には 2 にマークをつ けてください。)

*社会貢献活動とは、球団による地域イベント等への参加、サイン会、野球教室、学校訪問、幼稚 園・保育園・保育所訪問、病院や福祉施設の慰問、その他の地域における活動を指します。
$1: 1$ 年あたり
) 日くらい
2: 機会がない

(19)あなたはA球団が、社会貢献活動を行っていることをどのくらい知っていましたか。（マークはひ とつ)
$1:$ 全く知らなかった
2: あまり知らなかった
3: 少し知っていた
4: 詳しく知っていた

(20) A球団に関して、以下の項目をどう思いますか。「1：全くそう思わない」から「7：非常にそう 思う」でお答えください。(それぞれマークはひとつ)

\begin{tabular}{|c|c|c|c|c|c|c|c|c|}
\hline & & \multicolumn{7}{|c|}{ 全くそう思わないた----ー非常にそう思う } \\
\hline & & 1 & 2 & 3 & 4 & 5 & 6 & 7 \\
\hline 1 & A 球団はB市の知名度を向上させている & 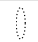 & & 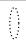 & 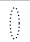 & 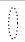 & 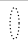 & 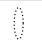 \\
\hline 2 & A球団はB市のイメージを高めている & 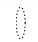 & $\therefore$ & 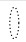 & 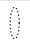 & 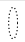 & 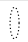 & 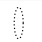 \\
\hline 3 & A球団はB 市に対する社会の認識を良くしている & 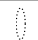 & 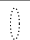 & 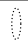 & 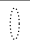 & 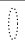 & 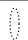 & 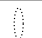 \\
\hline 4 & 私はA球団の動向が気になる & 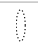 & 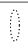 & 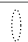 & 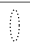 & 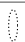 & 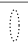 & 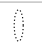 \\
\hline 5 & 私はA球団が存在することで日常生活での充実感を感じる & 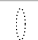 & 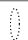 & 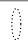 & 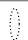 & $\therefore$ & 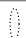 & 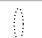 \\
\hline 6 & あなたは今後、A球団の試合をスタジアムで観戦したいと思いますか & 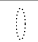 & ) & 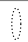 & 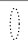 & 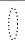 & 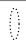 & 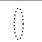 \\
\hline
\end{tabular}

(21)あなたはYYYY年MM月DD日にC 駅周辺で開催された「A球団優勝パレード」を見ましたか。（マーク はひとつ)
$1:$ 沿道で見た
2: テレビで見た
3: 見なかった

(22)あなたは以前に比べて、この $1 \sim 2$ 年の間でA球団が親しみ深くなったと思いますか。「 1 : 全く そう思わない」から「7：非常にそう思う」でお答えください。(マークはひとつ)

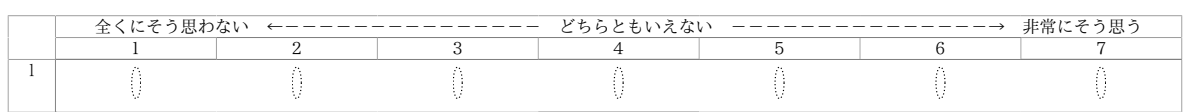

(23)あなたはA球団が存在することでB市やB市民にどのような効果をもたらしていると思いますか。 当てはまるものを以下の中からお選びください。(マークはいくつでも)
1: 地域の知名度・イメージの向上
2 : 共通の話題提供
$3:$ 地域の連帯感の向上
4: 地域への愛着心・誇りの醸成
5: スポーツ振興
6: 家族のコミュニケーションの向上
7: 家族で共にする時間の増加
8: 日常生活の充実感
$9:$ 青少年教育
10: 経済効果
11：試合観戦による娛楽・喜び
12: その他(具体的に：

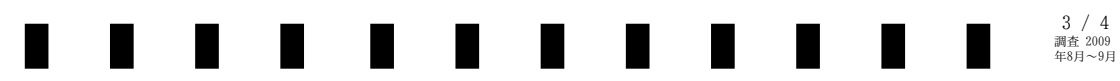




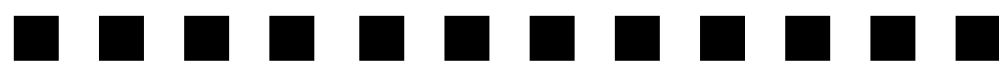

次の設問における説明文はすべて仮定の話です。この設問で用いる手法は、仮想的な状況を想定 し、もともと市場(価格)がない財・サービスに対する人々の金銭的な評価をたずねる仮想市場法と 呼ばれるものです。この手法により B市におけるプロスポーツチーム ( A 球団)の価值を推計しよう としています。これにより B 市民の皆様が考えているプロスポーツチーム( A 球団)の価值が定量的 な評価額として明らかになります。なお、この設問は早稲田大学が学術研究を意図として設定した ものです。

(24)プロ野球球団が球団を維持・発展させていく為には、選手人件費をはじめとした多くの資金を必要 としています。

A球団の財務状態が著しく悪化し、球団存続が困難な状況にあるとします。そこで、球団存続を維持 するために、B市民から寄付金を集めて基金を設立することと仮定します。

あなたは、1 年あたり1000円の寄付金を支払つていただけますか。お支払いただく分だけ自由に使え るお金が減ることをよく考えて、お答えください。(マークはひとつ)
$1:$ は
2: いいえ

(25)【設問(24)で「はい」とお答えされた方にお尋ねします。】それでは、1 年あたり3000円なら寄付 金を支払つていただけますか。（マークはひとつ）
$1:$ はい
2: いいえ

(26)【設問(24)で「いいえ」とお答えされた方にお尋ねします。】それでは、1 年あたり500円なら寄 付金を支払つていただけますか。(マークはひとつ)
$1:$ は
2: いいえ

（27）【全員にお尋ねします。】それでは、具体的に 1 年あたりいくらまでなら寄付金を支払つていただ けますか。（お支払いただける場合には1にマークをつけ、その金額をご記入ください。お支払いただ けない場合には 2 にマークをつけてください。)
1: 1 年あたり
) 円
2: 払わない

(28)【設問(27)で「払わない」とお答えされた方にお尋ねします。】その理由としてあなたの考えに最 も近いものをお答えください。(マークはひとつ)
1: 寄付金を支払う経済的な余裕がない
2: 自分や家族の生活には関係がなく、関心がない
3: 球団は必要だが、寄付金による支援に反対である
4: その他(具体的に:

(29)あなたの年収(税込)はおよそどれくらいですか(年金、アルバイト、パートなども含めます)。以下 の中からお選びください。(マークはひとつ)
1:0 199万円
2: 200万円〜399万円
3: 400万円〜 599万円
4: 600万円〜 799万円
5:800万円 999万円
6: 1000万円〜 1499万円
7:1500万円以上

(30)今回の調査についての感想、ご意見がありましたら自由にご記入ください。

質問は以上です。ご協力有難うございました。ご回答済みのアンケート用紙は、同封の返信用封筒にて 9月14日(月)までに、投函してくださいますようお願い申し上げます。

早稲田大学大学院スポーツ政策研究室

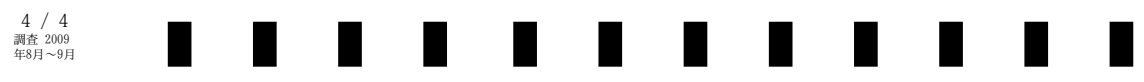

